\title{
PEMAHAMAN HADIS AHMAD HASSAN DALAM PERSPEKTIF SOSIOLOGI PENGETAHUAN
}

\author{
Maula Sari \\ Universitas Islam Negeri Sunan Kalijaga \\ J1. Laksda Adisucipto Sleman Yogyakarta \\ e-mail: maulasari68@gmail.com
}

\begin{abstract}
:
The emergence of A. Hassan as a moderate scholar who reformed Islam by using the Back to Quran blog was controversial in some circles. Ahmad Hassan, known as a reform figure or tajdid who is also known as ishlah, gave his thoughts in the field of hadith. The domination of the fiqh of the school for him has prevented Muslims from interacting with the Koran and the hadiths directly. With Ahmad Hassan's social context that has influenced him. This paper discusses the understanding of A. Hassan's hadith both textually and contextually. This writing uses a qualitative research library type. The author draws several conclusions. First, by looking at the sociology of knowledge he departed from the reformer, then there was tajdid and ishlah. Secondly, regarding pure worship, he used textual, while muamalah, etc. he used contextual hadith.
\end{abstract}

Keywords: Ahmad Hassan, Textual and contextual, Sociology of Knowledge.

\begin{abstract}
Abstrak:
Munculnya A. Hassan sebagai ulama moderat yang melakukan pembaharuan Islam dengan berslogan Back to Quran menjadi kontroversial dibeberapa kalangan. Ahmad Hassan yang dikenal sebagai satu tokoh pembaruan atau tajdid ysang dikenal juga dengan ishlah sangat memberikan pemikirannya dalam bidang hadis. Padahal, Dominasi fikih mazhab bagi beliau telah menghalangi umat Islam dalam berinteraksi dengan al-Quran dan hadist secara langsung. Dengan konteks sosial Ahmad Hassan yang telah mempengaruhinya. Tulisan ini membahas mengenai pemahaman hadis A. Hassan baik secara tekstual maupun kontekstual. Penulisan ini menggunakan kualitatif berjenis Library research. Penulis mengambil beberapa kesimpulan. Pertama, Dengan melihat sosiologi pengetahuan beliau yang berangkat dari pembaharu, maka terjadilah tajdid dan ishlah.Kedua, Mengenai ibadah murni beliau memakai tekstual, sedangkan muamalah, dll beliau menggunakan hadis kontekstual.
\end{abstract}

Kata Kunci: Ahmad Hassan, Tekstual dan kontekstual, sosiologi Pengetahuan

\section{A. PENDAHULUAN}

Pengaruh globalisasi akan selalu mengakibatkan pergeseran pengetahuan dan pendidikan bangsa. ${ }^{1}$ Keberagaman bentuk pola sikap dan perilaku politik menggunakan kata islam itu tentunya berawal dari suatu keprihatinan moral dan doktinal terhadap ketuhanan komunitas spiritual Islam. Faktorfaktor timbulnya keberagaman Indonesia. Pertama, adanya al-Quran dan hadis yang menjadikan peluang perbedaan pemikiran. Kedua, adanya penafsiran yang berbeda dari

\footnotetext{
1 Henricus Suparlan, "Filsafat Pendidikan KI Hadjar Dewantara Dan Sumbangannya Bagi Pendidikan Indonesia," Jurnal Filsafat Vol. 25, No. 1 (Februari 2015). 57.
}

ulama yang menafsirkan ayat tersebut. Ketiga, adanya situasi sosial yanag dihadapi oleh ulama. Keempat, adanya perbedaan metode dan pendekatan yang digunakan dalam memecahkan masalah. Kelima, adanya tujuan dan motif yang ingin dicapai. Keenam, karena terdorong dalam membuktikan bahwa ajaran Islam sebagai agama yang lengkap terhadap masalah umat. ${ }^{2}$

$$
\text { Banyaknya perdebatan dalam }
$$
sosiologi pengetahuan sering dijadikan justifikasi oleh banyak kalangan umat Islam

2 Abuddin Nata, Manajemen Pendidikan: Mengatasi Kelemahan Pendidikan Islam di Indonesia (Kencana, 2012). 263. 
untuk melakukan perpindahan paradima. $^{3}$ Tanpa adanya keprihatinan terhadap keberlakuan dan keberlanjutan nilai-nilai spiritual yang merupakan dasar dari suatu komunitas spiritual tersebut, maka kita tidak bisa menemukan adanya sikap politik Islam. ${ }^{4}$ Paham keagamaan di Indonesia belum sepenuhnya sesuai dengan tuntunan al-Quran dan hadis, sebagai sumber otoritatif ajaran Islam $^{5}$ dan pengembangan hadis juga kurang mendapatkan perhatian dari para ulama di Indonesia. ${ }^{6}$ Dalam konteks inilah A. Hassan meramaikan keagamaan Indonesia dengan perdebatan lisan. Berkat pendiriannya yang tegas dalam memegang ajaran al-Quran dan hadis Hassan meyakini ajaran tersebut membuat Islam sempurna. ${ }^{7}$

Pendidikan Islam harus berkembang pula dengan munculnya pembaharuan pendidikan Islam seperti Persatuan Islam (Persis). ${ }^{8}$ Pemikiran beliau sangat bagus dijadikan rujukan bagi intelektual para aktivis pergerakan islam modernis seperti Sarekat Islam, Muhammadiyah, Persatuan Islam, dan al-Irsyad. ${ }^{9}$ Beliau mengatakan bahwa hak politik umat Islam di Indonesia telah dirampas oleh penjajah yang memang sangat berkepentingan untuk menghapus perjuangan Islam politik di satu sisi, dan Kalangan bangsa Indonesia sendiri yang tidak berideologi Islam dalam pergerakannya. $^{10}$ A. Hassan melakukan pendekatan kontekstual terhadap berbagai teks hadis. Bahkan ia menggunakan pertimbangan Ihtisan, 'urf, maslahah

3 Muhammad Imdad, "Menjajaki Kemungkinan Islamisasi Sosiologi Pengetahuan," Kalimah Vol. 13, N. 2 (2015). 237.

4 Taufik Abdullah, Islam dan Masyarakat: Pantulan Sejarah Indonesia (Jakarta: LP3ES, 1987). 4.

5 M. Fatih, "Hadis Dalam Perspektif Ahmad Hassan," Mutawatir: Jurnal Keilmuan Tafsir Hadis 3, no. 2, Desember 2013 (t.t.).

6 Muhammad Rosyadi, "Pemikiran Hadis Abdurrauf As-Singkili Dalam Kitab Mawa'izat AlBadi'ah," Diroyah Vol. 2, No. 1 (2016). 56.

7 Syafiq A. Mughni, Hasan Bandung: Pemikir Islam Radikal (Surabaya: Bina Ilmu, 1994). 26

${ }^{8}$ Persis lahir dari ide alumni Darul Ulum Mekkah yakni $\mathrm{H}$. Zamzam dan temannya yang bernama $\mathrm{H}$. Muhammad Yunus. Ide mengenai pengambilan ajaran Islam kepada ajaran murni al-Quran dan Hadis. Persis mursalah, dan fatwa-fatwa yang dikeluarkannya. ${ }^{11}$ Penyampaian fatwa hadist Nabi beliau menggunakan perkara maslahat, dan inilah menjadi bukti bahwa tradisi yang dibangun A. Hasssan adalah fokus argumentasi yang mampu menggunakan pendekatan tekstual dan juga kontekstual sekaligus, baik kasus berlainan dalam memahami suatu hadis. ${ }^{12}$ Tulisan ini ingin melihat perkara tekstualitas dan kontekstualitas Ahmad Hassan dalam memahami suatu hadis dengan pengetahuan dan latar belakang pendidikan yang beliau miliki.

Tulisan ini menggunakan penelitian kualitatif, yaitu prosedur penelitian yang menghasilkan data deskriptif berupa katakata tertulis atau lisan dari orang-orang dan perilaku yang diamati. Data yang didapatkan kemudian dikumpulkan dan diuraikan dengan menganalisis. Penelitian ini berfokus pada dua bentuk data yaitu primer dan sakunder. Primer didapatkan dari buku A. Hassan dan hadis-hadis yang beliau terjemahkan. Sedangkan sakunder dari literatur penunjang. Adapun jenisnya library research atau penelitian pustaka. ${ }^{13}$

\section{B. PEMBAHASAN}

\section{Biografi Ahmad Hassan}

Ahmad Hassan atau dikenal dengan Hassan bin Ahmad (kemudian dikenal dengan Ahmad Hassan Bandung) lahir di Tamil, Singapura pada 1887. Ayahnya bernama Akhmad berasal dari India yang mempunyai gelar dengan Pandit. ${ }^{14}$

lahir pada tanggal 12 September 1923 di Bandung. Lihat Dadan Wildan, Sejarah Perjuangan Persis 1923-1983 (Bandung: Gema Syahid, 1995). 30-31.

9 Husnul Aqib Suminto, Politik Islam Hindia Belanda (Jakarta: LP3ES, 1997). 64.

${ }^{10}$ Suminto. 65.

11 Akh Minhaji, A Hassan: Sang Ideologi Reformasi Fikih di Indonesia (1887-1958), (Garut: Pembela Islam, 2015). 270.

12 MUhammad Ridwan Nurrohman, "Pemikiran Hadis di usantara; Antara Tekstualitas dan Kontekstualitas Pemikiran HAdis Ahmad Hassan," Diroyah Vol. 2, No. 1 (September 2017): 28.

13 Sedarmayanti dan Hidayat, Metodologi Penelitian (Bandung: Mandar Maju, 2011). 23.

14 Dalam masarakat India, mereka yang mempunyai ilmu agamanya secara mendalam digelar sebagai pandit, sebagaimana halnya dikalangan 
Sedangkan ibunya bernama Hajjah Muznah lahir di Surabaya dari keturunan keluarga yang berasal dari wilayah India. ${ }^{15}$ Ahmad Hassan memulai pendidikannya di kampung Kapur, Singapura. Beliau pertama kalinya mendapatkan ilmu dari orang tuanya sendiri. Ayahnya sangat menekankan pentingnya ilmu bahasa. Sehingga ia dituntut untuk mempelajari bahasa Arab, Inggris, Melayu, dan Tamil. Selain ahli dalam bidang kebahasaan, beliau juga senang menggeluti pertukangan ketika ia sedang dalam kesenggangan waktu luangnya. Ketika tidak belajar di sekolah, ia juga membantu ayahnya di percetakan sehingga ia senang dalam menulis dan mengarang. Pada tahun 1911, Ahmad Hassan menikahi perempuan keturunan Tamil-Melayu yang berasal dari keluarga pedagang. Perempuan itu bernama Maryam serta dikaruniai tujuh orang anak, yakni Abdul Qadir, Jamilah, Abdul Hakim, Zulaikha, Ahmad, M. Sa'id, dan Manshur. ${ }^{16}$

Seiring berjalannya waktu, keilmuan Ahmad Hassan semakin berkembang. Keahliannya mengenai agama terutama ilmu tafsir, ilmu hadis, fiqih, dan manthiq. Pada tahun 1924, Hassan berangkat ke Bandung untuk belajar tenun selama 9 bulan lamanya. Selama di Bandung, ia menetap di keluarga K.H.M. Yunus, seorang pendiri Persatuan Islam (Persis). ${ }^{17}$ Dan ia banyak berkenalan dengan banyak tokoh-tokoh Persis, antara lain Asyari, Tamim Zamzam. Perkenalannya ini membuatnya sering di panggil untuk mengajar dalam pengajian Persis. Tahun 1926, Ahmad Hassan mulai membangun usaha pertenunan di Bandung. Namun ditutup karena kesulitan dalam memperoleh bahan-bahannya. Kemudian ia sibuk mengikuti pengajian Persis. Sehingga

masyarakat Bugis digelar dengan Pandrita atau Ulama.

15 Amiruddin, "Pemikiran Pendidikan Ahmad Hassan," Kariman Vol. 05, No. 1 (2017): 23.

16 A. Mughni, Hasan Bandung: Pemikir Islam Radikal. 22.

${ }^{17}$ Persis lahir dari sebuah ide alumnus Darul ulum Mekkah H. Zamzam dan temannya H. Muhammad Yunus. Ide-ide mengenai Pengembalian ajaran Islam kepada ajaran yang murni yaitu al-Quran dan Hadis. Berbagai diskusi yang mereka lakukan dan terbesit mendirikan sebuah organisasi yang kemudian disebut membuatnya tertarik untuk bergabung dalam organisasi Persatuan Islam pada tahun 1926, tiga tahun setelah berdirinya Persis. Di tahun 1940, A. Hassan pindah ke Bangil, Jawa Timur serta membangun Pesantren Persatuan Islam Bangil. ${ }^{18}$

Beliau juga dikenal dengan pemimpin persis yang memiliki andil besar saat memberikan ajaran Islam dalam gerakan Persis. Setelah 17 tahun di Bandung, Persis juga telah dikenal di masyarakat luas, pada tahun 1941 Hassan hijrah ke Bangil. Disana ia terus menulis, dan mengembangkan keilmuannya. Di tahun 1956, ia menunaikan haji dan jatuh sakit. Keadaan demikian dibawanya pulang ke tanah air. Lalu datang lagi penyakit barunya, yaitu infeksi yang menyebabkan kakinya harus di potong. Pada tanggal 10 November 1958 Hasan meninggal dunia pada usia 71 tahun.

Rumah sederhananya terkenal dengan majalahnya "Pembela Islam". Diterbitkan dengan kertas HVS dan menggunakan tinta biru. Jarang kita dapatkan ulama yang begitu rajin bekerja dengan segala kesungguhan hatinya. ${ }^{19}$ Karya-karya Ahmad Hassan dalam al-Quran dan tafsir: Tafsir Al-Furqan, Tafsir Al-Hidayah, Tafsir surah Yasisn, dan Kitab Tajwid. Dalam bidang Hadis, fiqih, dan ushul fiqih: soal jawab: tentang berbagai masalah agama, pengajran shalat, risalah ijma',tarjamah bulghul maram.Dalam bidang sejarah: AlMukhtar, Sejarah Isra 'Mi'raj. ${ }^{20}$

\section{Pemikiran Hadis Ahmad Hassan}

Ahmad Hassan merupakan sosok ulama moderat, yang mana selalu menjunjung tinggi dialog dan diskusi. Tidak

persatuan Islam (Persis). Lahir pada 12 September 1923 di Bandung. Lihat Wildan, Sejarah Perjuangan Persis 1923-1983. 30-31

18 Syafiq A. Mughni, "Posisi Hassan Dalam Reform islam di Indonesia"," Program Studi Sejarah Peradaban Islam Vol. 1, No. 1 (September 2017). 9.

19 A. Hassan, Soal-Jawab Tentang berbagai Masalah Agama (Bandung: DIPENOGORO, 1968). 1169.

20 Nurrohman, "Pemikiran Hadis di usantara; Antara Tekstualitas dan Kontekstualitas Pemikiran HAdis Ahmad Hassan." 
mematok kebenaran hanya pada pemahamannya sendiri saja. ${ }^{21}$ Beliau selalu siap dalam mempertimbangkan maslahat dan madharat dari setiap pemikiran yang dilontarkannya. Buktinya, beliau membolehkan bunga bank akan tetapi melarang wanita berada di dewan dan diatas podium. Tentu saja hal tersebut dapat dilihat dan dibuktikan melalui realitas yang berlaku hingga masa sekarang. ${ }^{22}$

Pengertian hadis menurut Hassan ialah omongan, perkataan, ucapan, dan ghalibnya terpakai buat perkataan Nabi saw, atau disebut dengan sabda Nabi saw. Pengertian ini berbeda dengan ulama lainnya ${ }^{23}$ yang membubuhkan makna hadis itu ialah perbuatan, serta taqrirnya Nabi saw. Mengenai sunnah, Hassan secara lengkap dalam mendefinisikan yaitu segala perkataan, perbuatan, dan taqrir Nabi saw. Tampaknya Hassan membedakan antara hadis dan sunnah. Definisi Sunnah lebih luas ketimbang hadis. ${ }^{24}$

Menurut Ahmad Hassan, pendidikan bertujuan untuk terbentuknya akhlak yang terpuji bagi peserta didik sesuai dengan alQuran dan hadis. Bagi beliau, seperti halnya Nabi Muhammad saw yang diutus untuk menyempurnakan akhlak manusia. Maka dari itu, pendidikan haruslah melahirkan siswa yang bersumber pada al-Quran dan sunnah. Benar apa yang disimpulkan oleh Akh Minhaji, bahwa A. Hassan dengan jargon kembali kepada al-Quran dan sunnah, tidak menampilkan diri sebagai seorang ulama yang jauh dari realitas masyarakat. ${ }^{25} \mathrm{Ia}$ pun melakukan pendekatan kontekstual terhadap berbagai teks. Bahkan ia menggunakan juga pertimbangan istihsan, urf, maslahah mursalah, dan juga istishab dalam fatwa-fatwa yang dikeluarkannya. ${ }^{26}$

\footnotetext{
${ }^{21}$ Nurrohman. 30.

${ }^{22}$ Nurrohman. hlm.236.

${ }^{23}$ Ramli Abdul Wahid, Sejarah Pengkajian Hadis di Indonesia (Medan: Perdana Mulya Sarana, 2010).

${ }^{24}$ Nawir Yuslem, "Metodologi Pemikiran HAdis Ahmad HAssan Dalam Tarjamah Bulug Al-Maram," At-Tahdis Vol. 1, No. 2 (Desember 2017): 22.
} hlm. 15 .
Pandangan beliau mengenai sumber hukum Islam merupakan poin yang sangat penting. Pengakuannya bahwa al- Quran dan hadis menjadi sumber Islam yang senantiasa tercermin dalam fikirannya bahkan menjadikan kerangka dalam berfikir. Maka disinilah muncul beberapa pandangan mengenai masalah agama. Seperti Ijtihad, ittiba', dan taqlid merupakan jalan yang biasa dipakai umat Islam dalam memahami dan mengamalkan ajaran agamanya. Menurut Hassan, ijtihad bisa terjadi kapan saja sejak zaman Nabi, sahabat, tabi' in, dan masa-masa selanjutnya. Sebab pada dasarnya agama mengharuskan setiap orang memahami dan mengamalkan agamanya melalui ijtihad, kecuali orang-orang yang tidak memenuhi syaratnya maka ia harus memilih alternatif yang kedua, yaitu ittiba' untuk menjadi mujtahid, haruslah mereka mengetahui bahasa Arab dan ilmunya, ilmu tafsir, usul Fiqih, ilmu hadis sekedar cukup memeriksa dan memahami arti dari maksud ayat alQuran dan sunnah. ${ }^{27}$

Hassan, sangat melarang orang Islam melakukan bid'ah. Karena kerasnya, kata Hassan, maka seseorang yang menghadiri acara yang didalamnya terdapat bid'ah juga haram, kecuali jika kedatangannya itu untuk mengubah bid'ah dengan tangan atau ucapan. Untuk lebih jelasnya, mari kita ikuti pendapatnya tentang tahlilan dan makanmakan dirumah orang yang mengalami kematian.Pertama, mengenai zikir-zikir yang dilafalkan, Hassan mengatakan bahwa tidak semua yang baik itu akan menjadi baik bila dilakukan di tempat yang salah, seperti zikir di tempat kematian. Sebab menurutnya, tidak ada riwayat hadis, pendapat sahabat maupun tabi'in.

Kedua, berkenaan dengan makanmakan di tempat kematian. Hassan

\footnotetext{
${ }^{25}$ Faujian Esa Gumelar, "Polemik A. Hassan dan Muchtar Luthfi Mengenai Paham Kebangsaan (19291935)," Patanjala Vol. 10, No. 3 (September 2018): 523.

${ }^{26}$ Minhaji, A Hassan: Sang Ideologi Reformasi Fikih di Indonesia (1887-1958), 270.

27 M. Fatih, "Hadis Dalam Perspektif Ahmad Hassan."
} 
beragumen bahwa menurut fikiran yang waras, orang yang susah jangan dibuat tambah susah. Justru di senangkan, dibantu, dan dihibur. Bagi keluarga yang ditinggalkan seolah ada keharusan untuk menyelenggarakan selametan meski sebenarnya ia tidak mampu. ${ }^{28}$ Telah berkata Abdullah bin Ja'far: “ ketika tersebar kabar wafatnya Ja' far, maka bersabdalah Nabi: "Hendaklah kalian buat makanan untuk ahli rumah Ja'far, sebab mereka kedatangan hal yang menyusahkan" (HR. Ahmad, Abu Dawud, Tirmizi, Ibnu Majah, Shaf'i, dan Tabrani. Kapasitas beliau dalam bidang hadis tak dapat di ragukan kembali. Menurutnya, pokok ajaran Islam ada dua. Al-Quran dan sunnah atau hadis. Menurutnya hadis dan sunnah itu sama. Baginya, tidak semua hadis dapat diamalkan dalam kehidupan sehari-hari. Menurutnya ada lima pokok hadis yang dapat menetapkan hukum bagi agama: ${ }^{29}$

Pertama hadis mutawatir, yaitu yang diriwayatkan dari nabi oleh orang banyak, lalu disampaikan untuk orang yang banyak pula. Orang-orang yang banyak itu mustahil dalam melakukan kebohongan atas nabi. Kedua hadis sahih li zatih, adalah hadis yang sahih secara sanadnya bukan karena dibantu oleh hadis yang lain. Ketiga hadis shahih li ghairih, yaitu hadis sah tetapi derajatnya dibawah shahih, lalu di topang dengan hadis yang semisalnya. Keempat, Hasan li zatih, ialah hadis sah tetapi erajatnya dibawah sedikit dari hadis shahih karena diantara rawi-rawinya ada rawi yang hafalannya sekali dua kali terganggu. Kelima, hasan li ghairih, adalah hadis yang lemahnya agak ringan, dan dibantu atau di kuatkan dengan semisalnya atau dengan jalan lain yang dapat diterima. Kelima macam hadis ini, dapat dikapai dalam menentukan suatu hukum, sedangkan hadis hasan li ghairih hanya dapat

\footnotetext{
${ }^{28}$ Tak kurang dari 600 pertanyaan ia jawab dengan lugas, tegas, dan argumentatif dengan dasar-dasar ayat al-Quran dan hadis. Lihat juga keterampilannya dalam menganalisis kualitas hadis, keluasan ilmu mengenai biografi rijal, dan ketelitiannya dalam menganalisis redaksi hadis Tarjamah Bulughul Maram, sebuah kitab yang memuat ratusan hadis hukum.

${ }^{29}$ Minhaji, A Hassan: Sang Ideologi Reformasi Fikih di Indonesia (1887-1958),. 271.
}

di pakai dengan hukum-hukum yang ringan. Seperti halnya hukum yang sunnah, mubah, atau makruh. Menurut A. Hassan yang dinamakan hadis shahih ialah: setiap perawinya tidak terenal sebagai pendusta, serta tidak juga di tuduh pendusta. Masingmasing perawi tersebut saling bertemu dan menerima hadis tersebut. Para perawi telah baligh dan beragama Islam. Hadis itu tidak berlawanan dengan hadis lain yang lebih kuat darinya serta tidak bertentangan dengan alQuran. Terakhir tidak mengandung illah atau cacat yang tersembunyi. ${ }^{30}$

Hadis hasan menurut beliau adalah hadis yang sama dengan hadis shahih. Hanya saja rawi-rawinya ada seorang perawi yang menyalahi rawi lainnya atau mempunyai hafalan yang sedikit kurang baik. Sedangkan hadis dhaif, menurutnya hadis ini memiliki tingkatan. ${ }^{31}$ Ada yang lemahnya sangat berat, yang mana hadis ini tidak bisa sedikitpun di pakai. Ada yang lemahnya kurang sedikit dari yang diatas, itu juga tidak bisa dijadikan hujjah. Namun, ada yang lemahnya ringan. disini beliau mengatakan bisa dijadikan hujjah apabila ditopang satu sanad yang semisal dengannya. Karenannya bisa naik menjadi hasan li ghairih. Mengenai hadis Qudsi, menurutnya hadis ini sama saja dengan hadis lainnya. Hassan disini sangat menolak pendapat yang mengatakan bahwa hadis qudsi pasti shahih. Karena dalam penelitiannya ia menemukan hadis qudsi yang shahih, hasan, dan dhaif. ${ }^{32}$

\section{Pemikiran Tekstual dan Kontekstual Hadis A. Hassan}

Dalam menghadapi hadis mengenai aspek ibadah murni, Hassan memahaminya secara tekstual. Sebab baginya, ibadah harus dijalankan sesuai agama. Baginya, seorang mukallaf yang meninggalkan shalat buka

\footnotetext{
30 M. Fatih, "Hadis Dalam Perspektif Ahmad Hassan." 25.

${ }^{31}$ Kinkin Syamsudin, "Analisis Pemikiran Hadis A. Hassan dalam buku kesopanan tinggi secara Islam," Diroyah Vol.2, No.2 (Maret 2018). 27.

32 Secara panjang lebar Hassan menjealskan persoalan ini dan beliau memberikan contoh bagi masing-masing kualitas dari masing-masing hadis tersebut.
} 
karena tidur atau lupa, ia tidak wajib menggantinya. Sebab. Bila ia menggantinya, berarti ia telah melakukan ibdah yang tidak di perintahkan oleh agama. Jadi, mengganti shalat apabila ia hanya tertidur dan kelupaan saja. Mengenai persoalan muamalah. Hassan sangat kontekstual dalam memahami sebuah hadis. Misalnya hadis mengenai memotong kumis dan memelihara jenggot. Hassan mengatakan bahwa Rasulullah memerintahkan umat Islam harus mengambil tindakan yang berbeda dari orang-orang Majusi dan Musyrik dalam hal jenggot atau kumis. Mereka tidak memelihara jenggot tetapi kumis. Keadaan ini menurut Hassan, tak lain karena pada zaman Rasulullah kaum Musyrik dan Majusi memakai pakaian yang sama dengan kaum muslimin. Ketika itu secara fisik tidak adanya perbedaan maka Rasulullah menuruh umat muslim untuk memanjangkan jenggot.

Hadis diluar ibadah atau aqidah, Hassan lebih cenderung memaknai secara kontekstual seperti hadist melihat bulan. Bahkan A. Hassan heran melihat para ulama yang menolak hisab saat menentukan awal Ramadhan, padahal sahur dan puasa tiap hari memakai hisab, yang seharusnya mereka menggunakan rukyat saat sahur dan berbuka puasa. ${ }^{33}$ Tampaklah bahwa beliau benarbenar berpegang teguh pada al-Quran dan sunnah dalam segala permasalahan. Lalu Hassan membawakan hadis , bahwa kami ummat yang bodoh, kami tidak pandai menulis dan menghitung bulan itu ada tiga puluh hari, ada dua puluh sembilan hari. Beliau mengomentarinya, hal ini tidak memberi arti terlarang kita mengetahui tanggal satu dengan menggunakan hisab, yang sudah nyata dan terbukti lebih tepat daripada cara melihat bulan (rukyat). Tidak selamanya A. Hassan menggunakan hadis secara tekstual, dalam konteks luar ibadah dan aqidah justru cenderung kontekstual. ${ }^{34}$

Sedangkan ketika ada hadis yang bertentangan A. Hassan Dalam masalah ini mengambil tiga metode dalam penyele-

\footnotetext{
${ }^{33}$ Yuslem, "Metodologi Pemikiran HAdis Ahmad HAssan Dalam Tarjamah Bulug Al-Maram."

${ }^{34}$ Yuslem.
}

saiannya: al-Jam beliau mengum-pulkan dua atau beberapa dalil yang nampak bertentangan, lalu keduanya di pilah pilih dan di dudukkan dalam tempatnya masingmasing. Kedua at-Tarjih, memilih yang terkuat diantara dua atau beberapa keterangan agama yang telah tidak dapat dikumpulkan. Metode ini hanya dapat dilakukan dalam hadis saja, al-Quran tidak, karena al-Quran semuanya sama kuatnya. Ketiga, AtTawaqquf yaitu apabila kedua keterangan tersebut tidak dapat dikumpulkan dan tidak dapat dipilih yang kuat. Metode ini hanya ada pada sejumlah sedikit hadis saja, dan tidak mungkin ada dalam al-Quran.

Menurut A. Hassan, dalam mengompromikan keterangan agama hendaklah dilakukan dengan dasar keterangan lainnya, bukan hanya dengan fikiran dan perasaan saja. Mengenai keterangan haruslah dirujuk pada keterangan juga. Mengenai hadis shahih yang melarang buang air besar dan kencing menhgadap kiblat, dalam Tarjamah Bulughul Maram, Hassan menerangkan bahwa ada beberapa riwayat shahih: Pertama, Jabir pernah melihat Rasulullah kencing dengan menghadap kiblat. Kedua, Ibnu Umar pernah melihat Rasulullah buang air besar dalam membelakangi kiblat. Ketiga, Ibnu Umar melihat kakus Rasulullah di rumah Hafsah menghadap kiblat. Keempat, Ibnu Umar pernah kencing menghadap kiblat dengan berdindingkan kendaraan. ${ }^{35}$

Menghadapi keterangan yang berlawanan tersebut, Hassan merekomendasikan dua cara. Pertama, memakai semua keterangan tersebut, dengan meyakini bahwa larangan itu berlaku di tempat terbuka, tidak di tempat yang berdinding. Cara ini disebut olehnya sebagai tariqat al-jam'i. Kedua, larangan itu dianggap bukan sebagai larangan haram, tetapi makruh. Cara ini juga disebut Hassan sebagai tariqat al-Jam'i dan cara yang pertamalah yang paling tepat dan baik.

Hassan juga menekakan kehati-hatian dalam membaca terjemahan dari ayat atau

35 M. Fatih, "Hadis Dalam Perspektif Ahmad Hassan." 
hadis, jika salah menerjemahkan maka otomatis salah memahami hadisnya. Mengenai pemikiran hadis berkaitan terjemahan dan syarah hadis banyak tertuang dalam bukunya Tarjamah Bulugh al-Maram. Sekilas bukunya hanya terjemahan. Tetapi jika dilihat seksama Hassan juga menjelaskan atau menyerah ulasan dari hadis-hadis dalam kitab Bulugh al-Maram, dengan ulasannya yang singkat dan mudahdi fahami. Kata tarjamah menurut Hassan bukan hanya menerjemahkan sebagaimana yang kita fahami pada umumnya. Namun terjemah itu juga bermakna tafsiran. Maksudnya menafsirkan suatu kalam dengan bahasa lain, memindahkan suatu kalam kepada bahasa yang mudah, membicarakan biografinya, dan pendahuluan. ${ }^{36}$ Perdebatannya dengan kalangan tradisionalis hingga merambas pada praktek ijtihad, A. Hassan berpendapat bahwa setiap muslim memiliki hak dalam berijtihad selama dia masih mampu. Dan pendapat inilah yang kemudian dibantah oleh kaum tradisionalis, karena menurut mereka yang boleh melakuan ijtihad ialah hanya ulama mazhab. ${ }^{37}$

\section{Pemikiran Sosial A. Hassan Islam dan Kebangsaan}

a. Teks

Secara etimologis, Ahmad Hassan kata politik ini berasal dari bahasa Greek yaitu polis yang bererti negeri, kota, atau bandar. Kemudian kata tersebut dipakai oleh orang Eropa dengan arti ilmu pemerintahan, mengemudikan urusan negara-negara. Lebih lanjutnya, beliau mengatakan bahwa politik itu merupakan suatu ilmu dan usaha dalam mengatur, mengurus, dan membela negara dengan segala upaya yang perlu di lakukan masing-masing. Baik itu pembelaanya dengan tujuan untuk mengangkat derajat, atau mempertahankan kemerdekaan. ${ }^{38}$

\footnotetext{
${ }^{36}$ Yuslem, "Metodologi Pemikiran HAdis Ahmad HAssan Dalam Tarjamah Bulug Al-Maram.” 23.

37 Wildan Imaduddin Muhammad, "Ormas Islam di Jawa Barat dan pergerakannya: Studi kasus Persis," Analisis Vol. XVI, No. 2 (t.t.). 87
}

Sedangkan Miriam Budiardjo menyimpulkan bahwa politik dalam suatu negara (satate) berkaitan dengan masalah kekuasaan (power) pengambilan keputusan (decision making), kebijakan publik (public Policy), dan alokasi (allocation or distribuion). ${ }^{39}$

Menurut A. Hassan mengenai pergerakan ialah :

Pergerakan Islam ialah usaha dan daya upaya yang dilakukan oleh segolongan Muslimin yang mementingkan keislaman di dalam satu negeri yang dibawah perintah asing untuk mendapatkan kemerdekaan yang seluasluasnya, dijalankannya hukum-hukum Islam dengan sempurna dalam hal keduniaan dan keakhiratan. Sedangkan pergerakan kebangsaan itu ialah usaha dan daya upaya yang dilakukan oleh orang-orang yang mendasar pergerakannya diatas kepentingan bangsa dengan tidak mengambil agama mereka, di dalam satu negeri yang dibawah perintah asing untuk mendapat kemerdekaan yang seluas-luasnya hingga dapat diajukan kepadanya hukum-hukum buatan sendiri, maupun setuju dengan salah satu agama yang ada di negeri itu ataupun bertentangan. ${ }^{40}$

Jadi, Hassan mengidentifikasikan suatu pergerakan dilihat dari asas atau dasar yang digunakan dalam suatu pergerakan, Penyikapan Ahmad Hassan dan kawankawannya terhadap permasalahan ideologi perjuangan salah satunya berwujud dalam bentuk tulisan-tulisan, misalnya pada tahun 1932 mereka menerbitkan sebuah "verslag" berjudul Risalah Debat kebangsaan. Bagi Hassan, seseorang tidak boleh mengorbankan jiwanya melainkan karena Allah, tidak karena bangsa atau tanah air. Jika seseorang mencintai kaumnya atau

38 A. Hassan, A.B.C. Politik, dalam Tiar Anwar Bachtiar (ed), Risalah Politik A. Hassan (Jakarta: Pembela Islam Media, 2012). 4.

39 Miriam Budiarjo, Dasar-Dasar Ilmu Politik (Jakarta: Gramedia Pustaka Utama, 2009). 14.

40 Hassan, A.B.C. Politik, dalam Tiar Anwar Bachtiar (ed), Risalah Politik A. Hassan. 116. 
bangsanya, menurutnya hal itu tidak dinamakan dengan "Ashabiyah yang terlarang dan tidak termasuk dalam urusan kebangsaan yang tidak di ridhai oleh Islam. Akan tetapi yang terlarang ialah seseorang menolong kaumnya atas melakukan kezhaliman. Sebab, kezhaliman itu adalah melakukan suatu kesalahan terhadap dirinya sendiri, atau meletakkan sesuatu bukan pada tempatnya, Ia menganalogikan orang yang menolong kaumnya atas melakukan perkara yang tidak benar itu sebenarnya bukan menolong, tetapi membantu dalam jalan kesesatan, sebagaimana orang yang menarik ekor unta buat dikeluarkan dari sumur, sudah tentu tidak bisa dinamakan ia menolong unta tapi malah menyakitinya. ${ }^{41}$

\section{b. Konteks}

Konsep Nasionalisme yang secara radikal digemborkan oleh Sukarno mendatangkan kritik, terutama dari kalangan pergerakan Islam. Diantaranya Ialah Agus Salim dan Ahmad Hassan. Walau Sukarno menyerukan kerja sama antara kelompok nasionalis dengan Islam, tetapi konsep nasionalisme yang digagas oleh Sukarno bermasalah oleh kalangan Islam. Karena ia dianggap mengangkat ide nasionalisme tersebut sejajar dengan agama.Agus Salim mengatakan pemikiran tersebut sangat membahayakan, dan menurut Ahmad Hassan sebagai paham yang sangat membahayakan, karena sifat netral-agama. Inilah yang menjadikan dasar alasan kelompok dari Persatuan Islam atau Persis di Bandung untuk menentang paham kebangsaan Sukarno. Dengan tokoh utamanya A. Hassan, Persis mengimbangi pemikiran nasionalisme netralagama Sukarno itu dengan mengedapankan ideologi Islam. Orientasi politik A. Hassan di pengaruhi oleh ideologi Pan-Islamisme yang dikumadangkan oleh Jamaluddin al-Afgani dan Muhammad Abduh yang kemudian diteruskan rasyid Ridha.

Pemikiran A. Hassan dalam hal ini berupa beberapa butir berikut: ${ }^{42}$
1. Kedaulatan berada di tangan Tuhan

2. Hukum tertinggi di dalam negara adalah Syari'at

3. Pemerintah adalah pemegang amanah Tuhan untuk merealisasikan kehendakkehendakNya

4. Pemerintah tidak boleh melakukan perbuatan-perbuatan yang melampaui batas yang telah digariskan oleh Tuhan

\section{c. Contoh Hukum shalat bagi Musafir}

Mengenai shalat Jumat bagi musafir, Dewan Hisbah PERSIS mengalami sidang beberapa kali, pada tahun 2001 mereka menetapkan bahwa "musafir tidak dikecualikan dari kewajiban Jumat, sedangkan hadis-hadis mengenai empat golongan yang dikecualikan dari kewajiban Jumat adalah sah dan hadis-hadis mengenai musafir yang dikecualikan dari wajib Jumat semuanya dhaif'. Keputusan ini di dasari dengan Firman Allah dalam surah al-Jumat ayat 9:

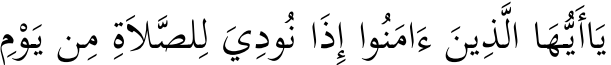

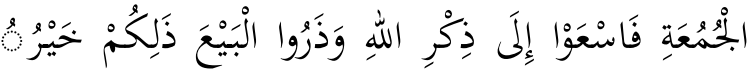

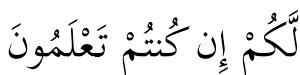

"Hai orang-orang yang beriman, apabila diseru untuk menunaikan shalat pada hari Jum'at, maka bersegeralah kamu kepada mengingat Allah dan tinggalkanlah jual beli. Yang demikian itu lebih baik bagimu jika kamu mengetahui", ${ }^{43}$

Hadis Rasulullah dalam riwayat $\mathrm{Abu}$ Dawud:

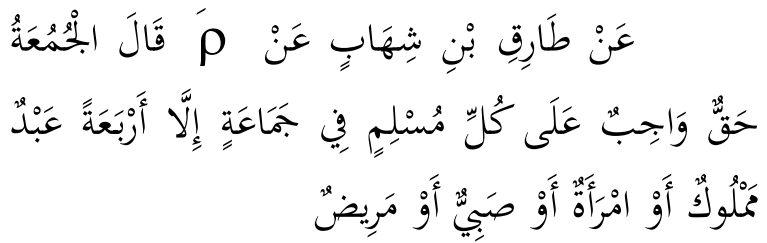

43 Rafid Abbas, Ijtihad Persatuan Islam (Yogyakarta: Pustaka Pelajar, 2013). 177.
${ }^{41}$ Hassan. 126.
${ }^{42}$ Hassan. 135. 
"Dari Tariq bin Syihab dari Nabi saw beliau bersabda, "Jumat itu merupakan hak yang wajib bagi setiap muslim secara berjamaah kecuali empat golongan: hamba sahaya, perempuan, anak-anak, dan orang yang sakit".

Dari kedua nash di atas, jelas mengenai siapa yang wajib shalat Jumat dan siapa yang tidak shalat Jumat. Musafir tidak disebutkan, jadi musafir wajib shalat Jumat. A. Hassan beliau pernah menerima pendapat K.H. Ma'sum mengenai tiadanya shalat Jumat bagi musafir, berdasarkan hadis yang mengecualikan musafir bersama perempuan, anak-anak, orang yang sakit, dan hamba sahaya, bukan berdasarkan tidak diceritakannya Jumat Rasul di dalam perjalannya. Sehingga yang dikecualikan dari kewajiban Jumat menjadi lima. Tetapi setelah ternayata hadis hadis-hadis yang menyatakan dikecualikannya musafir dari kewajiban Jumat itu dhaif, rujuklah beliau kepada pendapat awalnya berdasarkan ayat dan hadis yang shahih, yaitu Jumat itu wajib atas setiap muslim kecuali empat. Bila membaca perjalanan safar seorang muslim. Dalam laporan itu tidak di singgungsinggung tidak disebut-sebut makan minumnya, atau sembahyang, itu tidak berarti dalam safarnya tidak makan atau minum atau tidak sembahyang, itu tidak berarti dia dalam safarnya tidak makan minum atau tidak sembahyang, sebab yang pertama adalah sesuatu yang sudah lazim dan kedua adalah kewajiban yang mesti dilaksanakan. ${ }^{44}$

Ahmad Hassan telah mengemukakan nash selain dari kedua nash diatas menunjukkan kewajiban bagi musafir untuk melaksanakan shalat Jumat, adapun kedua

${ }^{44}$ Abbas. 179.

45 Menurut A. Hassan berdasarkan kedua hadis diatas menunjukkan bahwa musafir wajib shalat Jumat, karena tidak termasuk ke dalam empat golongan tersebut. Adapun yang tidak mewajibkan shalat Jumat bagi musafir itu didasarkan pada kitab fiqih sunnah 2 dan lainnya, yang banyak dijadikan sebagai pegangan bagi ulama. Dalam kitab tersebut dijelaskan bahwa nabi saw pernah safar pada hari Jumat, yaitu pada haji wada' tetapi nabi saw tidak shalat Jumat, hanya shalat Jama' antara zuhur dan nash tersebut, yaitu hadis yang diriwayatkan oleh Nasa'i,yang berbunyi:

$$
\text { الجمعة واجب على كل محتلم }
$$

"Shalat Jumat itu wajib atas tiap-tiap orang yang sudah baligh"

Dari Hadis yang diriwayatkan oleh Abu Dawud dan Hakim, berbunyi:

$$
\begin{aligned}
& \text { الجمعة حق على كل مسلم في جماعة الا اربعة } \\
& \text { عبد محلوك او امراة او صبي او مريض }
\end{aligned}
$$

"Jumat itu suatu ketentuan yang wajib atas tiap-tiap muslim dengan berjamaah kecuali empat, yaitu hamba milik perempuan, anak-anak, dan orang sakit". ${ }^{45}$

\section{KESIMPULAN}

Ahmad Hassan muncul sebagai peran ulama moderat yang sangat terampil dalam perannya. Dengan melihat sosiologi pengetahuan beliau yang berangkat dari pembaharu, maka terjadilah tajdid dan ishlah. Taklid mazhab merupakan sesuatu yang paling beliau tidak sukai, dan bid'ah terhadap segala sesuatu. Dengan sosiologi pengetahuan yang melatarbelakangi beliau dalam mendirikan PERSIS Ajakan Back to al-Quran dan sunnah menjadi pacuan utama beliau. Hadis mengenai ibadah murni, Ahmad Hassan melihat secara tekstual hadis tersebut karena itu semua harus dijalankan sesuai agama, al-Qur'an dan hadis, sedangkan muamalah, dan diluar ibadah beliau melihat secara kontekstual maka tampaklah bahwa memahami hadis nabi harus dapat menempatkan pemahaman sesuai kehendak agama.

ashar. Namun pendapat dewan Hisbah PERSIS ini telah melemahkan hadis-hadis yang tidak mewajibkan musafir wajib shalat Jumat, dalam arti pendapat Dewan Hisbah PERSIS ini sama dengan pendapat A. Hassan. Dengan alasan bahwa nabi saw tidak shalat jumat pada hujjatul wada' itu karena hujjatul wada' ketika wuquf di arafah itu jatuh pada hari Sabtu, bukan pada hari Jumat. Jadi kewajiban musafir untuk melaksanakan shalat Jumat itu atas dasar nash yang telah disebutkan di atas. 


\section{DAFTAR PUSTAKA}

A. Mughni, Syafiq. Hasan Bandung: Pemikir Islam Radikal. Surabaya: Bina Ilmu, 1994.

"Posisi Hassan Dalam Reform islam di Indonesia"." Program Studi Sejarah Peradaban Islam Vol. 1, No. 1 (September 2017).

Abbas, Rafid. Ijtihad Persatuan Islam. Yogyakarta: Pustaka Pelajar, 2013.

Abdullah, Taufik. Islam dan Masyarakat: Pantulan Sejarah Indonesia. Jakarta: LP3ES, 1987.

Amiruddin. "Pemikiran Pendidikan Ahmad Hassan." Kariman Vol. 05, No. 1 (2017): 23.

Budiarjo, Miriam. Dasar-Dasar Ilmu Politik. Jakarta: Gramedia Pustaka Utama, 2009.

Gumelar, Faujian Esa. "Polemik A. Hassan dan Muchtar Luthfi Mengenai Paham Kebangsaan (1929-1935)." Patanjala Vol. 10, No. 3 (September 2018): 523.

Hassan, A. A. Hassan, Soal-Jawab Tentang berbagai Masalah Agama. Bandung: DIPENOGORO, 1968.

A.B.C. Politik, dalam Tiar Anwar Bachtiar (ed), Risalah Politik A. Hassan. Jakarta: Pembela Islam Media, 2012.

Imdad, Muhammad. "Menjajaki Kemungkinan Islamisasi Sosiologi Pengetahuan." Kalimah Vol. 13, N. 2 (2015).

M. Fatih. "Hadis Dalam Perspektif Ahmad Hassan." Mutawatir: Jurnal Keilmuan Tafsir Hadis 3, no. 2, Desember 2013 (t.t.).

Minhaji, Akh. A Hassan: Sang Ideologi Reformasi Fikih di Indonesia (18871958), . Garut: Pembela Islam, 2015.

Muhammad, Wildan Imaduddin. "Ormas Islam di Jawa Barat dan pergerakannya: Studi kasus Persis." Analisis Vol. XVI, No. 2 (t.t.).

Nata, Abuddin. Manajemen Pendidikan: Mengatasi Kelemahan Pendidikan Islam di Indonesia. Kencana, 2012.

Nurrohman, MUhammad Ridwan. "Pemikiran Hadis di usantara; Antara Tekstualitas dan Kontekstualitas Pemikiran HAdis Ahmad Hassan." Diroyah Vol. 2, No. 1 (September 2017): 28.

Rosyadi, Muhammad. "Pemikiran Hadis Abdurrauf As-Singkili Dalam Kitab Mawa'izat Al-Badi'ah." Diroyah Vol. 2, No. 1 (2016).

Sedarmayanti dan Hidayat. Metodologi Penelitian. Bandung: Mandar Maju, 2011.

Suminto, Husnul Aqib. Politik Islam Hindia Belanda. Jakarta: LP3ES, 1997.

Suparlan, Henricus. "Filsafat Pendidikan KI Hadjar Dewantara Dan Sumbangannya Bagi Pendidikan Indonesia." Jurnal Filsafat Vol. 25, No. 1 (Februari 2015).

Syamsudin, Kinkin. "Analisis Pemikiran Hadis A. Hassan dalam buku kesopanan tinggi secara Islam." Diroyah Vol.2, No.2 (Maret 2018).

Wahid, Ramli Abdul. Sejarah Pengkajian Hadis di Indonesia. Medan: Perdana Mulya Sarana, 2010.

Wildan, Dadan. Sejarah Perjuangan Persis 1923-1983. Bandung: Gema Syahid, 1995.

Yuslem, Nawir. "Metodologi Pemikiran HAdis Ahmad HAssan Dalam Tarjamah Bulug Al-Maram." AtTahdis Vol. 1, No. 2 (Desember 2017): 22 